\title{
Reflections of Inequalities: The Construction of HIV/AIDS in Africa in the Australian Print Media.
}

\author{
Kathryn Wenham \\ School of Public Health \\ Griffith University \\ Neil Harris \\ School of Public Health \\ Griffith University \\ Bernadette Sebar \\ School of Public Health \\ Griffith University
}

\begin{abstract}
The HIV/AIDS pandemic in sub-Saharan Africa prompted industrialised nations to initiate a coordinated global response, which to date has been inadequate in reducing the pandemic's impact in Africa. To better understand this response, this article explores the portrayal of the pandemic in the Australian print media using critical discourse analysis to unpack the discourses surrounding the construction of the pandemic. In particular, it examines how issues of power, ideology, causation and responsibility are expressed and utilised to validate certain stances and responses. The findings demonstrate that the media presents a particular perspective on the pandemic that favours the agendas of industrialised nations. Linguistic devices uncovered racist, medical and development discourses that gave voice to industrialised nations and silenced those from sub-Saharan Africa, limiting discussion on alternative responses. These findings highlight the utility of critical discourse analysis in understanding power structures that construct and influence responses to public health issues.
\end{abstract}

Keywords: HIV/AIDS, critical discourse analysis, sub-Saharan Africa, media, sociology

\section{Introduction}

Over the past two decades, the Human Immunodeficiency Virus/Acquired Immunodeficiency Syndrome (HIV/AIDS) pandemic has developed into an international crisis warranting a coordinated global response (Barnett and Whiteside 2002). The response, however, has not significantly curbed the crisis in sub-Saharan Africa, the region where HIV/AIDS is most prevalent (UNAIDS/WHO 2007). There, high infection and mortality rates, limited access to treatment, and widespread social and economic disadvantage are having a devastating impact on the lives of many African people (The World Bank 2008; UNAIDS/WHO 2007). Consequently, the global community needs to reconsider and improve its current response to the pandemic in sub-Saharan Africa. A necessary step in that process is to examine the discourses surrounding the response in order to better understand how it has been framed to date. 
This study analyses the portrayal of the HIV/AIDS crisis in sub-Saharan Africa by utilising critical discourse analysis to interpret how the pandemic has been constructed in the media. Much research has been done on how the media represents HIV/AIDS in industrialised nations and this has shown how negative concepts and stereotypes can inhibit the ability of health workers and the community to address the pandemic (Kitzinger and Miller 1992; Austin 1990; Patton 1990). However, far fewer studies have looked at how the media in industrialised nations portray HIV/AIDS in the so called less or least developed nations. Therefore, there is limited understanding of the contextual and deeper meaning of the discourses surrounding HIV/AIDS in Africa by people in industrialised nations such as Australia. How the media portrays this global health issue and its solutions reflects the power structures shaping public health thinking in the international community (Alleyne, 1997; Herman and Chomsky, 2002). This study aims to explain how the discourses surrounding HIV/AIDS in Africa have been represented in the Australian print media and to explain how issues of power, ideology, causation and responsibility are expressed and utilised to validate certain stances and responses to the pandemic and to ignore others.

\section{Research approach}

\section{Discourse analysis as theory and method}

This study applies critical discourse analysis to examine the Australian print media's portrayal of the HIV/AIDS pandemic in sub-Saharan Africa. Discourse analysis can reveal underlying power relations in society through examining discursive structures and the discourses surrounding an issue (van Dijk 2001). One way of uncovering these discourses is to examine the role of language in constructing perceptions of the social world and how language is used to promote and reproduce dominant values and ideologies held by particular social groups (Mills 2004; Lupton 2003; van Dijk 2001). In this instance, analysing the construction of the HIV/AIDS pandemic in the media can assist us to understand the associated international power relations that interact with and shape this pandemic. As Thusssu (2008:2) notes, news is "a vehicle for engagement in the democratic process, feeding off and into domestic politics and international relations". In recognition of the power of ideology in the construction of health, public health researchers have used discourse analysis to analyse representations of health issues (Lupton 1992). The greater understanding such analysis brings has helped to challenge exploitation and stigmatisation, which are obstacles to effective health promotion and treatment (Scannell 1998; Lupton 1992).

A strength of critical discourse analysis lies in its systematic deconstruction of texts according to textual and linguistic features such as active and passive constructions, ideological squares, local coherence and implied propositions (van Dijk 2001, 1998, 1988). This enables the researcher to uncover assumptions and ideologies otherwise overlooked by the casual reader. The rich textual structure of the print medium makes it an important starting point to analyse the discourses surrounding an issue.

\section{Data collection and analysis}

Data was derived from articles from major newspapers in Australia's three largest capital cities from December 01, 2000 to November 30, 2002 inclusive. This period was chosen as it reflects the most recent intense period of coverage in terms of HIV/AIDS and Africa in the Australian print media. Newspaper convention places the most important terms and elements of news earlier in the news article, particularly in 
the headline and lead paragraph. The more frequent appearance of the subject terms HIV/AIDS and Africa in the headline or lead paragraph in those years suggests that 2000 to 2002 were the most recent intense period of the development of this discourse and laid the foundation for media discussions of the topic today. In contrast, in subsequent years the subject terms appeared less in the headline and lead paragraph and more frequently in the body of news articles, but mostly as a reference point (e.g. as a comparison or as one of many global issues) rather than the main topic of the article. Aside from this change in focus, textual analysis of more recent articles found little difference between that foundational period and current coverage.

The newspapers included The Australian (national), The Sydney Morning Herald, The Sunday Telegraph and The Daily Telegraph Mirror (Sydney), The Age and The Herald-Sun (Melbourne), and The Courier Mail and The Sunday Mail (Brisbane). Both quality broadsheet and tabloid newspapers were included to ensure varied articles and readership. The researchers conducted a database search for the terms AIDS and Africa using Factiva, a database covering all articles in key Australian news and business publications. Inclusion of the term HIV did not yield any further results. From the resultant media archive, the researchers used purposive sampling to obtain an information rich sample that included text containing a lot of varied information on HIV/AIDS in Africa. This usually included articles where the main focus was HIV/AIDS in Africa as opposed to articles where this issue was merely a reference point. The texts where HIV/AIDS in Africa was only a reference point were very similar in their statements and so only a few representative articles were used from this group.

A three-stage analysis process was conducted. The first involved one researcher reading all 407 articles to gain an overview, and then coding them according to their topic (e.g. AIDS issues, African politics and business, development, global issues, popular culture and celebrities, science and drugs and miscellaneous). These topics were clearly defined to ensure accuracy and consistency and selections were confirmed by a second researcher. When articles covered multiple topics, preference was given to the topic identified in the headline and lead paragraph. This division into topics was done to ensure maximum variation sampling by covering a variety of topics for the in-depth analysis rather than inadvertently concentrating on a limited topic surrounding HIV/AIDS. The second stage involved choosing articles for analysis two at a time from each topic until saturation within each topic was reached. The articles chosen from each topic were chosen for intensity, or those articles that were more information rich and would provide more material for analysis. According to the standard structure of newspaper articles, articles that featured the subject terms of AIDS and Africa more frequently earlier in the text would have a greater focus on the subject. This resulted in a total of 50 articles being analysed in depth. These were from various newspapers: The Australian (16), The Sydney Morning Herald (8), The Daily Telegraph Mirror (3), The Age (7) and The Herald-Sun (8), The Courier Mail (7) and The Sunday Mail (1). This provided good coverage of the three cities as well as both broadsheet and tabloid publications.

The researchers systematically analysed the texts using van Dijk’s $(2001,1998,1988)$ socio-cognitive framework, which examines a variety of linguistic devices used within texts. This well-established framework was chosen because it provides a consistent and objective structure for the analysis and helps reduce bias by offering 
various analytical tools to explore issues within the texts. The use of tools to address the syntax and semantics of textual structure, as well as production and comprehension of texts provides greater objectivity and multiple modes of analysis to improve validity. Two other researchers reviewed the data to confirm the results and reduce the risk of bias. When the analysis uncovered aspects of texts that varied from the others, these were examined for similarities with one another and differences to the main body of texts to offer an explanation for this discrepancy. These are outlined in the findings.

Data analysis was conducted according to Van Dijk’s $(1998,1988)$ socio-cognitive framework for discourse analysis, which examines the structure, production and comprehension of texts. Rather than analyse the HIV/AIDS pandemic as a whole, the analysis focused on four key themes: power and ideology, causation, responsibility and responses. Power and ideology are key areas of investigation in van Dijk's (2001, 1988) critical discourse analysis. Causation, responsibility and responses are themes that emerged from the literature as important in the discourses surrounding the general HIV/AIDS pandemic in the media. Power is the ability to control or influence others, the environment or physical and political resources (van Dijk 2001; Rothgeb 1993). This includes the authority to define and construct meanings. Scannell (1998) defines ideology as a distorted system of values and beliefs used to promote the interests of a social group. In this context, power and ideology refer to the structure of power and the system of values and beliefs used to maintain that structure. Language both reflects and shapes social order (Jaworski and Coupland 1999:3). Therefore, the choice of language is never neutral but can be used to subtly promote certain power structures and ideologies (Lupton 1998). In addition, the promotion of certain power structures and ideologies within a discourse often normalises them and can limit the reader's ability to imagine alternatives. The theme of causation focuses attention upon whom or what the media portray as causing the pandemic. The next theme relates to how the newspaper texts portray responsibility for the HIV/AIDS pandemic in subSaharan Africa. The ability of local coherence to expose cause and consequence made it a particularly useful tool in understanding how the texts attribute cause and responsibility. The theme of responses refers to what the texts proffer as the recommended solutions to the HIV/AIDS pandemic in sub-Saharan Africa. Deconstructive tools that address structure, production and comprehension were used for each of the four themes in order to uncover elements that are fundamental to the textual portrayal of the themes within the discourse.

\section{Findings and discussion}

\section{Themes and elements identified in the discourse}

For each of the four themes, power and ideology, causation, responsibility, and responses, a number of elements emerged through the analysis of the structure, production and comprehension of the texts. Power and ideology both influence and are influenced by causation, responsibility and responses. Causation also influences responsibility, which in turn influences responses. These four themes, and the elements that constitute them, collectively make up an explanation of the discourses surrounding HIV/AIDS in sub-Saharan Africa in the Australian print media. The findings of the study relating to each of these themes are outlined in the following sections.

\section{Power and ideology}


In this context, the analysis of the newspaper articles enabled the deconstruction of power and ideology embedded within the text as the interrelated elements of: sources and voices; representations of people and institutions; and influence of other discourses.

\section{Sources and voices}

Overall, the study found that the articles invariably used institutions and people in industrialised nations for quotes and as expert sources, in particular, United Nations (UN) representatives and agencies and non-government organisations (NGOs) and their representatives based in industrialised countries. For example, the UN reported on the "feminisation of AIDS" (Herald-Sun 2002:37), and Malcolm Fraser of CARE Australia cautioned that "those living in extreme poverty" are more vulnerable to AIDS (Sunday Mail 2001:31). Scientists and academics from industrialised nations were commonly cited commenting on the causes and consequences of the pandemic. For example, an AIDS conference report on the effects of war on HIV/AIDS rates (Pollard 2002:8) and the Population Resources Center in the United States predicted negative population growth in many African countries due to AIDS (Fraser 2002:9). Government or ex-government officials, businessmen and celebrities from industrialised nations were also frequently cited as experts, advancing their personal credibility in this area.

In contrast, African sources were predominantly local eyewitnesses and African government officials or leaders, such as Thabo Mbeki and Nelson Mandela. The following extract about a Kenyan girl addressing Australian schoolchildren illustrates how the texts constructed the credibility of many Africans through their status as eyewitnesses, rather than as experts:

[The girl], 15, who lost both parents to HIV/AIDS... told the children that because her mother is dead she does all the domestic work at the home she shares with her brothers, as well as going to school. (Hill-Douglas 2001:3)

The texts highlighted the origins and qualifications of experts such as "Robert Siliciano, professor of medicine at Johns Hopkins University in Baltimore in the US" when they were from industrialised nations (Henderson 2002:8). However, African experts were not identified or quoted less frequently than their counterparts from the industrialised world. Even accounting for the easier media access to Western experts, the de-emphasis of the origin of African experts suggests that African origin somehow detracts from their credibility. This represented people from industrialised nations as credible sources of knowledge regarding issues affecting African people while suggesting that few, if any, African experts exist. This portrayal empowers the industrialised nations to define HIV/AIDS according to their own interests. In addition, the use of Africans predominantly as eyewitnesses and the lack of representation of African experts and AIDS workers portrays Africans as merely reacting to the pandemic rather than taking the initiative to fight it. For example, Thabo Mbeki's government is described negatively as one that“...refuses to accept the epidemic's reality" (The Age 2002:6). In contrast, portrayals of people and organisations from industrialised nations were more commonly proactive: "Gates to fight HIV/AIDS in Africa” (The Australian 2002a:11). 
The dichotomies presented are consistent with racist discourse portrayals of Africans as passive, helpless victims and people from industrialised nations as knowledgeable and resourceful (Treichler 1999). Many Africans working to fight AIDS and assist those affected are voiceless within the media (Treichler 1999), which is significant as research suggests that empowerment and health are linked (Schoepf 1995).

\section{Representations of people and institutions}

The element of representations of people and institutions relates to how the texts presented the characteristics and actions of stakeholder groups. Van Dijk $(1998,1988)$ identified ideological squares as important linguistic devices used to portray people. Ideological squares occur when texts highlight the positive in-group and negative outgroup actions. They also play down the negative in-group and positive out-group actions (Van Dijk 1998, 1988).

Within the sample, ideological squares frequently highlighted the positive actions of the industrialised nations. For example, the industrialised world was portrayed as knowledgeable, "The prime minister said Australia was a world leader in combating HIV/AIDS and its expertise will help health specialists and communities in Africa deal with this crisis" (The Australian 2002b:2); generous, "Australia has...donated an extra \$11.5 million to campaign against AIDS in Africa” (The Australian 2002b:2); and proactive, "Gates to fight AIDS in Africa" (The Australian 2002a:11). In contrast, the texts portrayed Africans as disaster ridden, 'teetering on the brink of self destruction' (Fraser 2002:9); poor, “14 million face starvation” (Daily Telegraph 2002:38); diseased, "sick, malnourished" (Bone 2001:7); passive, as the South African government is described as "a government that refuses to accept the epidemic's reality" (The Age 2002:6); ignorant, "an act that is unmatched in its ignorance and its self-destructiveness" (Goforth 2002); and irresponsible, "destroying the same animals that may help us understand HIV/AIDS” (Goforth 2002). In addition, texts often portrayed African leaders as irresponsible and incompetent, such as the "Tragic delusions of Thabo Mbeki” (The Age 2002:6).

In contrast, positive actions of Africans were under-represented. The infrequent mention of grassroots community programs to help those affected by HIV/AIDS and poverty, and people with few resources caring for orphans and others affected by the pandemic (Yallop 2002:11; Treichler 1999) paled in comparison to negative representations of Africans (Bone 2001:7; Bone 2002:19; Fraser 2001:14; Fraser 2002:9; Goforth 2002; The Age 2002:6). Furthermore, the few exceptions to these positive and negative portrayals were commonly represented as unusual cases such as Nelson Mandela, Kofi Annan and 11 year old AIDS activist Nkosi Johnson. Museveni's actions to reduce HIV/AIDS in Uganda were praised in the same text as he was criticised for saying that there were no homosexuals in Uganda (Courier Mail 2002). Although he was praised, the criticisms were the main focus of the text.

In keeping with this portrayal, the positive aspects of the industrialised nations were highlighted and negative actions ignored or de-emphasised. Reports on mining companies were indicative of this: "Mining giant Anglo American is to provide tens of thousands of South African mine workers with anti-AIDS drugs in an attempt to stave off catastrophic losses of trained workers" (du Venage 2001:35). This quote glorifies the positive actions of the mining company, yet ignores the role of mining companies in the spread of HIV/AIDS. Mining companies initially set up cheap 
housing for workers in order to save the companies from paying higher wages (Worden 2000). This environment separated workers from their families for most of the year, increasing the likelihood of social and family breakdown and extramarital sex, all contributors to HIV/AIDS (Yeboah 2007; Irwin et al 2003; Worden 2000). The widespread existence of ideological squares within the texts reflects the power of the industrialised nations to promote their own interests. This is also evident in the inclusion of the racist, medical and development discourses.

\section{Influence of other discourses}

This element relates to the presence within the newspaper articles of discourses that are well established in industrialised nations. These include the development, racist and medical science discourses (Kitzinger and Miller 1992; Patton 1990). The development discourse was evident in the promotion of aid from rich countries (The Australian 2002a; Sunday Mail 2001). The racist discourse was obvious in the emphasis on 'problematic' African cultural practices such as 'promiscuous' sexual practices (Bone 2002) and hunting primates for food (Goforth 2002). Promotion of scientific opinion, scientific research and medical treatments such as anti-retroviral drugs (ARDs) reflect the medical science discourse (Henderson 2002; du Venage 2001). These discourses support and reinforce one another as they are based on the assumption of the superiority of industrialised nations over 'less developed' nations and scientific over other forms of knowledge (Marshall 2005; Escobar 1995). The global development discourse favours economic growth and incorporates racist discourse by portraying those who are "underdeveloped" or "developing" as inferior and in need of assistance (Escobar 1995). The medical discourse favours Western medical and scientific knowledge over alternative knowledge and approaches. It commonly orients attention to the diagnosis and treatment of disease within the individual and detracts attention from social, economic and environmental influences on health (Marshall 2005; Germov 2005). These three established discourses embedded within the HIV/AIDS discourse provide familiar structures and models that guide the reader's comprehension of HIV/AIDS in Africa. They also deter alternative ways of understanding. Together these discourses work to exclude and disempower Africans by exerting the power of the industrialised nations to assign responsibility, define causes and determine solutions to the pandemic. For example, an article on The World Bank and AIDS stated:

We now understand better than ever what causes poverty and what cures it...[and]...have decided it is time to put more resources into implementing that understanding and making serious progress (Colebatch 2002:15).

The texts did not reveal the limitations of these discourses and rarely promoted alternative discourses that shift the balance in power relations towards Africa. The only exception was the human rights discourse, which appeared in a limited manner regarding women's rights and also to support the medical discourse in promoting access to ARDs in Africa. The emergence of the human rights discourse is a promising step towards providing a balance within the discourse on HIV/AIDS in Africa, however a survey of more recent media texts revealed little progress in this regard. On the whole, the use of these three discourses within the texts works to naturalise industrialised nations as superior and African nations as inferior. Within all the elements under power and ideology, the linguistic tools illustrated the balance of 
power to be in favour of the industrialised world. The main exceptions were the portrayal of 'exceptional' Africans and the emergence of the human rights discourse. This same power and dominance can also shape views on causation.

\section{Causation}

In examining the texts to identify elements of causation, particular attention was paid to local coherence, or the conditional links between sentences or propositions, which is an important tool for revealing causative factors in critical discourse analysis (van Dijk 1988, 1998). Causative elements that emerged from the discourse included: biological agents of transmission (e.g. organisms that cause disease), lifestyle and behavioural factors (e.g. actions and behaviours that contribute to the spread of disease), and poverty (which many view as a contributing factor to disease).

\section{Biological agents of transmission}

The texts reflected the general scientific consensus that a biological agent, namely HIV, is the primary cause of AIDS (Barnett and Whiteside 2002). This was illustrated with the common use of the term "HIV/AIDS" and statements that used the two terms interchangeably, implying a link. This shared understanding allowed readers to infer the cause within the texts, reflecting the assumption that this causal link is indisputable or common sense.

To emphasize this presupposition, the press reported that South African president Thabo Mbeki contested this causal link (Fraser 2001:14; The Age 2002:6). Articles presumed his view to be incorrect with no further evidence or discussion required, highlighting the universal acceptance of this link. Although the role of biological agents in HIV/AIDS together with the primary routes of transmission are well established, the strong emphasis on these factors orients attention to biological and lifestyle issues. In turn, this orientation hampers the consideration of socio-economic factors which many academics, AIDS workers and African leaders, such as Mbeki, believe to be underpinning the pandemic (Farmer 1996; Sunday Herald Sun 2002:40).

\section{Lifestyle and behavioural factors}

The element of lifestyle and behavioural factors relates to the identification of lifestyle factors as important in contributing to the spread of HIV/AIDS. These factors included behavioural factors such as unsafe sexual practices, "the sexual behaviour of men has to change” (Dwyer 2000:12); lack of use of condoms (O’Loughlin 2001:10); high prostitution rates sometimes called "survival sex" (Bone 2002:19); cultural factors such as the bushmeat trade (i.e. hunting primates for food) (Goforth 2002); gender relationships (particularly the oppression of women) (Bone 2002:19); dry sex (Bone 2002:19); and the myth that sex with a virgin can cure a man of HIV/AIDS (Ballantine 2002:45). The emphasis on sexual behaviour and promiscuity fits the racist discourse, which identifies Africans as dirty, lacking in self-control and given to deviant sexual practices (Marshall 2005; Austin 1990; Kitzinger and Miller 1992; Lupton 2005; Patton 1990). This contrasts with the idea of populations of industrialised nations as more sexually restrained (Austin 1990).

Similarly, highlighting cultural practices reinforces modern/primitive, and rational/irrational dichotomies. For example, a Harvard academic described the bushmeat trade as "an act that is unmatched for its ignorance and its selfdestructiveness" (Goforth 2002). Although the article did identify the lack of choices 
available to the hunters, the strong words and well-credentialed source serves to reinforce the stereotypes.

\section{Poverty}

The third element of causation was poverty. In contrast to the consensus assumed for biological and lifestyle causes of HIV/AIDS, poverty was a more contentious issue, with controversy increasing as the causal link intensified. While many academics and experts strongly argue that poverty markedly contributes to the AIDS pandemic, the sample did not reflect this significantly (Yeboah 2007; Barnett and Whiteside 2002; Farmer 1996; Irwin et al 2003; Poku 2002; Schoepf et al 2000). Although the texts raise poverty as a contributing factor, socioeconomic causes were overshadowed by biological and behavioural causes. Instead, socioeconomic factors were linked to an inability of individuals to access treatment and of nations to mount behavioural and prevention campaigns and access drug treatment. While these are valid issues, most texts played down the inability of nations to address the underlying social and economic inequities that lead to health inequalities. Some texts acknowledged that Mbeki and his government sought to highlight the role of poverty in the spread of HIV/AIDS such as in the statement that "The real problem in Africa is poverty" (Sunday Herald Sun 2002:40). Mbeki was also identified as knowing that "the dimension of the AIDS pandemic in his country is almost certainly insoluble, given the parlous state of the economy" (Fraser 2001:14). However, the texts also discredited Mbeki, casting doubt on his expertise with descriptions such as "unorthodox beliefs" and "delusions" (The Age 2002) and the "extraordinarily inept manner in which Mr Mbeki has handled the AIDS nightmare" (Fraser 2001:14). All these factors combine so that the texts promote biological and lifestyle factors over socio-economic factors rather than acknowledging the multi-determinants of the HIV/AIDS pandemic and the associated need for multi-strategy and multi-level responses.

\section{Responsibility}

The analysis identified the theme of responsibility as comprising the two elements: African origin and transmission; and solutions offered by the industrialised world.

\section{African origins and transmission}

The element of origin and transmission relates to how the texts explain responsibility for causing the pandemic. Predominantly, the newspaper articles held Africans responsible for causing the AIDS pandemic, originally via the bushmeat trade: "Most scientists agree that HIV emerged when simian immunodeficiency viruses, HIV cousins that are carried by non-human primates, spread to people in west-central Africa” (Goforth 2002). It then spread through "promiscuous" and unprotected sexual activity (Dwyer 2000:12; Bone 2002:19; O’Loughlin 2001:10). The texts implied that the ignorance of Africans contributed to these actions. Occasionally African leaders tried to attribute the pandemic to European nations but the same texts discredited these leaders, casting doubt over the logic of their allegations. In these ways, the texts firmly position responsibility for the pandemic with the least developed nations, including African people.

\section{Solutions offered by the industrialised world}

The element of solutions orients upon responsibility for solving the crisis. In contrast to the positioning of responsibility for the origins and transmission of the pandemic, 
the texts suggested that the industrialised nations are more able and responsible to address the pandemic in Africa than Africans. For example, the texts portray the industrialised world as powerful and capable saviours: "Australia takes lead in world fight against AIDS epidemic" (Riley 2001:6). Examples of those responsible to address the pandemic included institutions such as the UN and international financial institutions, national governments (through aid programs and technical assistance), NGOs, scientists (via research activities) and the private sector, especially drug companies (through allowing access to anti-retroviral drugs). These are all dominated by the industrialised world.

The texts presented few Africans working to fight against AIDS, and these were presented as extraordinary. For example, a Zulu community worker is described as "fomenting cultural revolution to combat the catastrophe of Africa's black plague HIV-AIDS' (Yallop 2002:11). The term “cultural revolution” suggests she is an exception in her cultural group, and implies that Africans need to change their culture in order to solve their problems and address HIV/AIDS. Thus the texts implied that the industrialised nations should address the pandemic because of their superior knowledge, skills, resources, culture and attitude.

The newspaper articles promoted international assistance as a central component of the solution. Texts identified insufficient resources in many African nations as a significant obstacle to addressing the pandemic. Yet, quotes such as the description of “...the global response to HIV/AIDS as a failure” (The Age 2001:12) suggested that assistance was not forthcoming from industrialised nations in a timely or adequate manner. Although a global solution is appropriate for a global pandemic (Poku and Whiteside 2006), it also enables the industrialised nations, as more powerful and the providers of resources, to invariably dominate the nature and make-up of any enacted solution.

\section{Responses}

The elements that emerged from the discourse relating to responses were: scientific and medical interventions; lifestyle changes; structural changes; and absence of responses (community participation and risk environments).

Before overviewing these elements, it is worth acknowledging that the absence of particular responses in the texts is also informative. In this regard, within the newspaper articles there is a paucity of examples of African communities fighting the pandemic which positions Africans as helpless victims requiring assistance from the more powerful and more "developed" industrialised nations (Treichler 1999). Commonly recommended public health responses such as community participation and addressing risk environments were largely overlooked (Barnett and Whiteside 2002; Baum 2008). The texts also downplayed alternative approaches, such as human rights, community participation, global economic changes or debt cancellation, which aim to create a more just and equitable society and empower local communities (Baum 2008; Schoepf et al 2000; Seidel 1993; Whiteside 2002). This lack of alternatives to established structures serves to promote solutions that maintain the status quo of a global system that has so far been unable to reverse the tide of the pandemic, and some would argue contributes to it (Schoepf et al 2000; Farmer 1996). 


\section{Scientific and medical interventions}

By far the most common and strongly recommended responses in the texts were scientific and medical interventions, particularly the use of anti-retroviral drugs (ARDs) and the development of a vaccine. Drug access was mainly centred on economic issues as many countries with high AIDS prevalence also experience extreme poverty, making ARDs unaffordable:

Last week's decision by 39 pharmaceutical giants to drop a legal battle to keep cheap anti-AIDS drugs out of South Africa is a victory for health workers who accused the companies of putting profits before lives. (The Australian 2001a:12)

The texts implied that access to ARDs is critical to reduce transmission and vulnerability to HIV/AIDS and for global equity (Barnett and Whiteside 2002; Irwin et al 2003; Poku 2002). While access to treatment is indeed vital, the above quote suggests promoting ARDs as the primary response likely financially benefits drug companies based in the industrialised nations with poorer nations required to pay for this treatment. This reliance upon ARDs promotes the medicalisation of HIV/AIDS as it positions drug treatment as the definitive solution rather than one strategy that forms part of a more integrative and comprehensive approach incorporating the socioeconomic and structural aspects of the pandemic (Myer et al 2003). Furthermore, it esteems scientific knowledge stemming from industrialised nations and neglects important social solutions that would utilise local knowledge and skills commonly devalued by the industrialised world (Marshall 2005).

The texts emphasised other medical solutions as evidenced by the prominence of the medical science discourse and scripts in the sample. However, the development of medical solutions has inherent difficulties and, to date, has realised only partial success (Barnett and Whiteside 2002). These limitations were noted in only one article. Although biomedical responses are important, neglect of socio-economic issues makes biomedical responses unsustainable due to lack of resources and infrastructure in those countries most affected (Barnett and Whiteside 2002).

\section{Lifestyle changes}

The promotion of lifestyle and behavioural responses was strongly evident in the texts. This follows on from the causative association between behaviour and health outcomes. The texts suggested that cultural and behavioural change will help fight AIDS as reflected in the following quotes: “...from primary school age they are given classes on HIV and AIDS” (Hill-Douglas 2001:3), “... the answer to this African tragedy ... must be found in poverty alleviation, cultural change...” (Bone 2002:19), "Male health workers in these countries are the first to tell you that such cultural practices are all for the (supposed) benefit of men, and must be changed if the epidemic is to be controlled" (Bone 2002:19), and “... the all-important strategy to beat HIV, namely changing the sexual behaviour of men" (Dwyer 2000:10). Such views suggest inherent problems with African cultures and behaviour (which are frequently homogenised within the media) (Austin 1990; Marshall 2005) and ignore positive aspects such as some of the various social and family structures that can help to buffer the effects of illness and disaster (Schoepf et al 2000). 
Although behavioural factors such as safe sexual practices are important in disease prevention, alone they have not and will not succeed in reducing the spread of HIV/AIDS and this was seldom recognised in the texts (Yeboah 2007). The behavioural approach can increase stigma, which is counterproductive to disease prevention, and ignores the socio-economic context of behaviours, including such matters as illiteracy and the economic dependence of women (Barnett and Whiteside 2002; Baum 2008; Goldin 1994; Muir 1991). The research literature promotes a generalised response to the pandemic, which means addressing socioeconomic, behavioural, medical and structural factors in an integrated manner (Baum 2008; Marshall 2005; Barnett and Whiteside 2002). However, the strong media focus on medical and behavioural solutions moves attention away from these broader responses.

\section{Structural changes}

The element of structural change is related to the broader societal changes needed to progress HIV/AIDS prevention. In particular, this element is focused upon poverty alleviation as a response to the pandemic. Poor infrastructure, nutrition, healthcare, education and treatment, increased commercial sex work, female dependency and migration for work are all commonly associated with poverty and contribute to the spread of HIV/AIDS (Yeboah 2007; Barnett and Whiteside 2002). Donating money is frequently presented as a solution: "please call ... to make a donation" (Sunday Mail 2001:31), "write a cheque" (Bone 2001:7); as is foreign aid: "Foreign aid works because it makes better futures possible" (Colebatch 2002:15).

Although resources and poverty alleviation are indeed vital to fight AIDS, donations and foreign aid are not sustainable in the medium to long term, and many argue they would not end poverty as they do not address the structural inequities in the global economic system (Marshall 2005; Gershman and Irwin 2000). In addition, these responses have inherent problems that were not identified within the newspaper articles (Gershman and Irwin 2000). Interestingly, alternative global strategies that could provide sub-Saharan Africa with greater equity and opportunity within the global system, such as debt alleviation or elimination of agricultural subsidies in industrialised nations, were denounced within the texts as not economically or reasonably viable (The Australian 2001b:23).

\section{Conclusion}

This critical discourse analysis has shown how the discourses surrounding HIV/AIDS in Africa in the Australian print media portray the pandemic in a particular manner. They do so by using a variety of linguistic devices. Sources and quotes gave voice primarily to those in the industrialised world. The racist, medical and development discourses provided a familiar basis to which readers could relate. Local coherence showed how different ideas were linked together to convey cause and consequence. Through these and other linguistic devices a number of assumptions and dichotomies emerged that are not obvious through a casual read of the texts. This analysis revealed that, despite the occasional exception, the media largely portrays the HIV/AIDS pandemic in sub-Saharan Africa in a way that promotes representations, dichotomies and solutions that advantage the industrialised nations, reflecting the power structures in the international community and biasing the global debate away from alternative solutions. It would be interesting to compare this representation with the portrayal of HIV/AIDS in Africa within African media and whether the traditional dominance of 
industrialised nations in global news flows would facilitate this inequality being similarly expressed in that context or whether local constructions would provide a counterbalance to those views.

This study has shown how critical discourse analysis can be used to reveal power inequalities in the discourses surrounding a global health issue. Although on the surface the texts often used politically correct language or seemingly presented a balanced view, a deeper examination of the texts revealed hidden biases and assumptions. These underlying biases and assumptions favoured the industrialised nations over the least developed nations and medical, behavioural and scientific solutions over more integrated solutions. Critical discourse analysis is a useful methodological tool, which can give an understanding of how HIV/AIDS in Africa is constructed by powerful groups and reflected in the media. This, in turn, gives us insight into current stances and responses by the industrial nations toward the pandemic and the need for alternative understandings and solutions. A more balanced representation of the stakeholders, the inclusion of the human rights discourse to a greater degree and the consideration of alternative integrated solutions could present a very different portrayal of the pandemic and perhaps influence our response to it. 


\section{References}

Alleyne, M.D. (1997) News Revolution: Political and Economic Decisions About Global Information St Martin's Press: New York.

Austin, S.B. (1990) 'AIDS and Africa: United States mass media and racist fantasy' Cultural Critique Winter 1989-90: 129-152.

Ballantine, D. (2002) 'Fighting the pain of a ravaged land' Sunday Herald Sun 24 November: 45.

Barnett, T. and Whiteside, A. (2002) AIDS in the Twenty-First Century: Disease and Globalization Palgrave MacMillan: Houndmills, Basingstoke.

Baum, F. (2008) The New Public Health ( $3^{\text {rd }}$ edn) Oxford University Press: Melbourne.

Bone, P. (2002) 'Why change is their only chance’ Sunday Age 1 December: 19.

Bone, P. (2001) 'Sign up here for the war on terror’ The Age 20 September: 7.

Colebatch, T. (2002) 'How we can do better on global poverty’ The Age 30 April: 15.

Courier Mail (2002) 'Europeans blamed for AIDS’ The Courier Mail 5 March: 5.

Daily Telegraph (2002) ‘14 million face starvation’ Daily Telegraph 18 September: 38.

Du Venage, G. (2001) ‘Anglo resolves to shaft AIDS’ The Australian 5 March: 35.

Dwyer, J. (2000) 'Tears for a dying generation in Africa' The Sydney Morning Herald 20 December: 10.

Escobar, A. (1995) Encountering Development: The Making and Unmaking of the Third World Princeton University Press: Princeton.

Farmer, P. (1996) 'Women, poverty and AIDS' in P. Farmer M. Connors and J. Simmons (eds) Women, Poverty and AIDS Common Courage Press: Monroe, Maine, pp. 3-38.

Fraser, J. (2002) 'Where it's September 11 every day of the year - 9/11 - The aftermath’ The Australian 13 September: 9.

Fraser, J. (2001) 'AIDS tidal wave earns contempt for hero' The Australian 27 January: 14.

Germov, J. (2005) 'Imagining health problems as social issues' in J. Germov (ed) Second Opinion: An Introduction to Health Sociology ( $3^{\text {rd }}$ edn) Oxford University Press: Oxford, pp. 3-27. 
Gershman, A. and Irwin, A. (2000) 'Getting a grip on the global economy' in J.Y. Kim; J.V Millen; A. Irwin and A. Gershman (eds) Dying for Growth: Global Inequality and the Health of the Poor Common Courage Press: Monroe, Maine, pp. 11-43.

Goforth, S. (2002) 'Feeding spread of AIDS' The Australian 10 August.

Goldin, C.S. (1994) 'Stigmatization and AIDS: critical issues in public health' Social Science and Medicine 39: 1359-1366.

Henderson, M. (2002) 'Change vital to cure AIDS’ The Australian 10 July: 8.

Herald-Sun (2002) ‘AIDS claims more women’ Herald-Sun 27 November: 37.

Herman, E.S. and Chomsky, N. (2002) Manufacturing Consent: The Political Economy of the Mass Media Pantheon: New York.

Hill-Douglas, O. (2001) 'Escape from the cycle of AIDS through education' The Age 31 October: 3.

Irwin, A.; Millen, J. and Fallows, D. (2003) Global AIDS: Myths and Facts South End Press: Cambridge, MA.

Jaworski, A. and Coupland, N. (1999) 'Introduction: perspectives on discourse analysis' in A. Jaworski, and N. Coupland (eds) The Discourse Reader Routledge: London, pp. 1-44.

Kitzinger, J. and Miller, D. (1992) '”African AIDS”: the media and audience beliefs' in P. Aggleton; P. Davies and G. Hart (eds) AIDS: Rights, Risks and Reasons The Falmer Press: London, pp. 28-52.

Lupton, D. (2005) 'The body, medicine, and society' in J. Germov (ed) Second Opinion: An Introduction to Health Sociology ( $3^{\text {rd }}$ edn) Oxford University Press: Oxford, pp. 195-207.

Lupton, D. (2003) Medicine as Culture: Illness, Disease and the Body in Western Societies ( $2^{\text {nd }}$ edn) Sage: London.

Lupton, D. (1998) 'Discourse analysis' in C. Kerr, R. Taylor and G. Heard (eds) Handbook of Public Health Methods, McGraw Hill: Sydney, pp. 491-495.

Lupton, D. (1992) 'Discourse analysis: a new methodology for understanding the ideologies of health and illness' Australian Journal of Public Health 16: 145150.

Marshall, W.E. (2005) 'Aids, race and the limits of science' Social Science and Medicine 60: 2515-2525. 
Mills, S. (2004) Discourse ( $2^{\text {nd }}$ edn) Routledge Taylor and Francis: London and New York

Muir, M.A. (1991) The Environmental Contexts of AIDS Praeger: New York.

Myer, L.; Morroni, C. and Susser, E. (2003) 'Commentary: The social pathology of the HIV/AIDS pandemic’ International Journal of Epidemiology 32: 189-192.

O’Loughlin, E. (2001) 'Dismay at Church’s stance on condoms’ The Sydney Morning Herald 1 August: 10.

Patton, C. (1990) Inventing AIDS Routledge: New York.

Poku, N.K. (2002) 'The global AIDS fund: context and opportunity' Third World Quarterly 23: 283-298.

Poku, N. and Whiteside, A. (2006) 'Introduction: 25 years of living with HIV/AIDS: challenges and prospects’ International Affairs 82(2): 249-256.

Pollard, R. (2002) 'UN forces more at risk from HIV/AIDS than war' The Sydney Morning Herald 11 July: 8.

Riley, M. (2001) 'Australia takes lead in world fight against AIDS epidemic' The Sydney Morning Herald 23 May: 6.

Rothgeb, J.M.J. (1993) Defining Power: Influence, and Force in the Contemporary International System St Martin’s Press: New York.

Scannell, P. (1998) 'Media - language - world' in A. Bell and P. Garrett (eds) Approaches to Media Discourse Blackwell: Oxford, pp. 251-267.

Schoepf, B.G. (1995) 'Action research and empowerment in Africa' in B.E. Schneider and N.E. Stoller (eds) Women Resisting AIDS: Feminist Strategies of Empowerment Temple University Press: Philadelphia, pp. 246-269.

Schoepf, B.G.; Schoepf, C. and Millen, J.V. (2000) 'Theoretical therapies, remote remedies: SAPs and the political ecology of poverty and health in Africa' in J.Y. Kim; J.V. Millen; A. Irwin and A. Gershman (eds) Dying For Growth: Global Inequality and the Health of the Poor Common Courage Press: Monroe, Maine, pp. 91-125.

Seidel, G. (1993) 'The competing discourses of HIV/AIDS in sub-Saharan Africa: discourses of rights and empowerment versus discourses of control and exclusion' Social Science and Medicine 36: 175-194.

Sunday Herald Sun (2002) ‘AIDS theory savaged’ Sunday Herald Sun 24 March: 40.

Sunday Mail (2001) ‘CARE urges world action on AIDS’ Sunday Mail 1 July: 31.

The Age (2002) ‘Tragic delusions of Thabo Mbeki’ The Age 6 April: 6. 
The Age (2001) 'HIV/AIDS epidemic on our doorstep’ The Age 8 October: 12.

The Australian (2002a) 'Gates to fight AIDS in Africa' The Australian 26 February: 11.

The Australian (2002b) 'Cash pledged for regional AIDS battles' The Australian 4 March: 2.

The Australian (2001a) 'Cheap drugs won't win the AIDS war' The Australian 23 April: 12.

The Australian (2001b) ‘Poor nations’ debt sting decried’ The Australian 23 April: 12.

The World Bank (2008) The World Bank's Commitment to HIV/AIDS in Africa: Our Agenda for Action, 2007-2011 The World Bank: Washington, DC.

Thussu, D. (2008) News as Entertainment: The Rise of Global Infotainment Sage: London.

Treichler, P. (1999) How to Have a Theory in an Epidemic Duke University Press: Durham.

UNAIDS/WHO (2007) AIDS Epidemic Update: December 2007 UNAIDS: Geneva.

Van Dijk, T. A. (2001) 'Critical discourse analysis' in D. Tannen; D. Schiffren and H. Hamilton (eds) Handbook of Discourse Analysis Blackwell: Oxford, pp. 352371.

Van Dijk, T. (1998) 'Opinions and ideologies in the press' in A. Bell and P. Garrett (eds) Approaches to Media Discourse Blackwell: Oxford, pp. 21-63.

Van Dijk, T. (1988) News as Discourse Lawrence Erlbaum Associates: Hillsdale, NJ.

Whiteside, A. (2002) 'Poverty and HIV/AIDS in Africa' Third World Quarterly 23: 313-332.

Worden, N. (2000) The Making of Modern South Africa Blackwell: Oxford.

Yallop, R. (2002) 'Crusader takes up arms against the scourge of a nation' The Australian 29 November: 11.

Yeboah, I.E.A. (2007) 'HIV/AIDS and the construction of Sub-Saharan Africa: Heuristic lessons from the social sciences for policy' Social Science and Medicine 64: 1128-1150. 